Section Editor

John J. Millichap, MD

Teaching NeuroImages:

\title{
Classic Ramsay Hunt syndrome and associated MRI findings
}

Edward Labin, MD Huseyin Tore, MD Mohammed Alkuwaiti, MD

Christopher Streib, MD, MS

Correspondence to

Dr. Streib: streib@umn.edu

Figure 1 Contrast enhancement of cranial nerves (CNs) VII and VIII in Ramsey Hunt syndrome
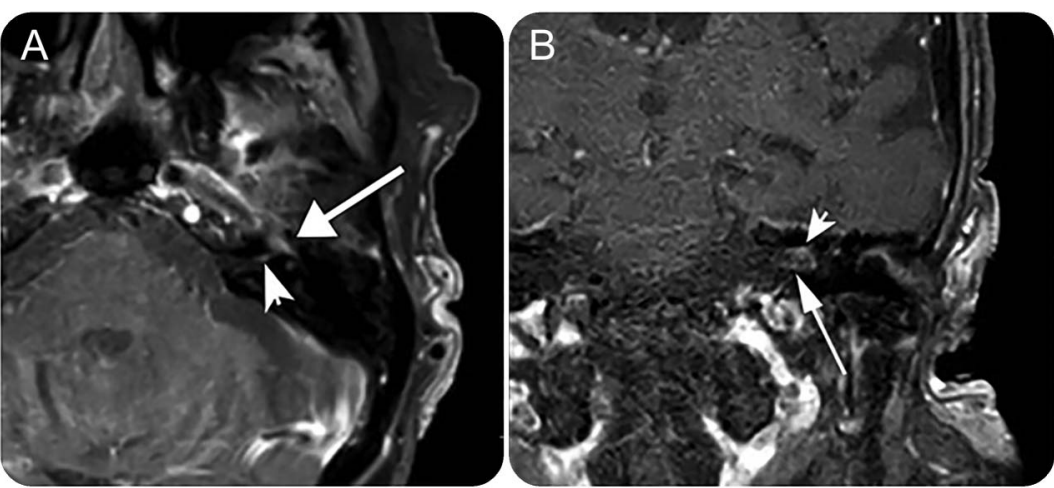

(A) Contrast enhancement of intracanalicular CN VII segment (arrowhead) and geniculate ganglion (arrow). (B) Contrast enhancement of intracanalicular segments of CN VII (arrowhead) and CN VIII (arrow). The contralateral CN VII and CN VIII appear normal.

An 85-year-old woman with dementia presented with left ear pain, vertigo, and mild left peripheral facial weakness of unclear chronicity. MRI demonstrated contrast enhancement of cranial nerves $(\mathrm{CNs}) \mathrm{VII}$ and VIII consistent with Ramsay Hunt syndrome $(\text { RHS })^{1}$ (figure 1). She was treated with steroids and acyclovir. On evaluation 4 days later, she had developed the classic RHS triad of ear pain, ipsilateral facial

Figure 2 Clinical presentation of Ramsey Hunt syndrome
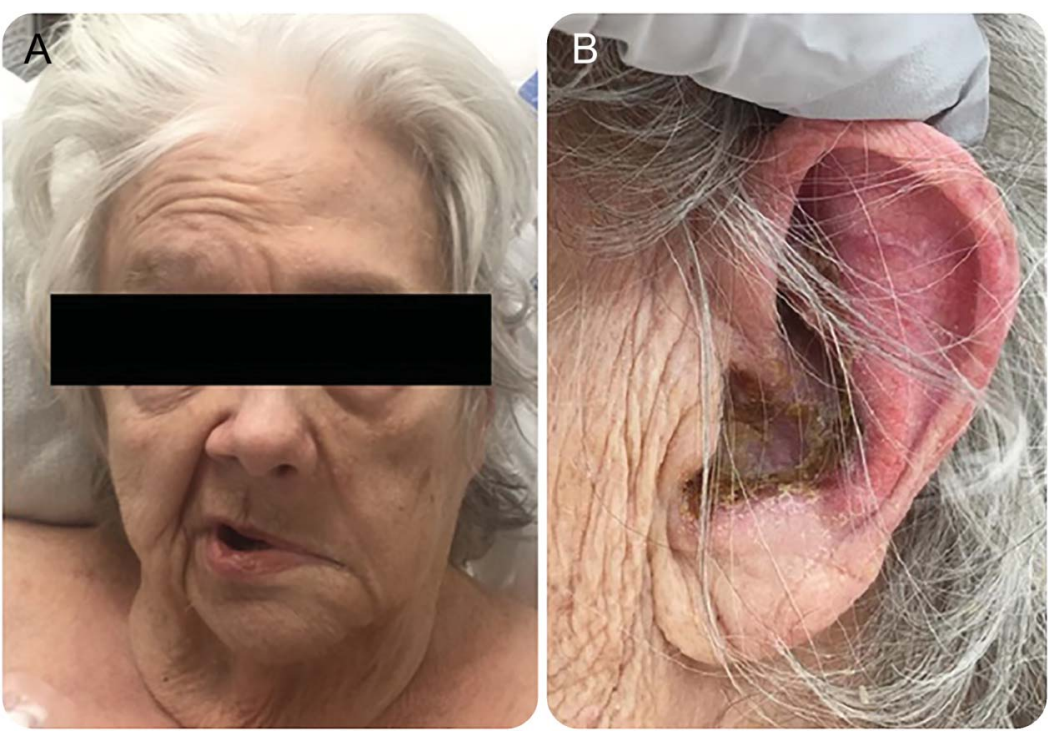

(A) Left facial paralysis with (B) encrusted vesicular rash in left ear.

Download teaching slides: Neurology.org

From the Department of Neurology, University of Minnesota, Minneapolis.

Go to Neurology.org for full disclosures. Funding information and disclosures deemed relevant by the authors, if any, are provided at the end of the article. 
paralysis, and vesicular rash, plus hyperacusis and persistent vertigo (figure 2$).^{2}$

In the appropriate setting, MRI demonstrating contrast enhancement of CN VII plus additional affected CNs (most commonly VIII) may allow diagnosis of RHS prior to onset of the classic vesicular rash.

\section{AUTHOR CONTRIBUTIONS}

Edward Labin: drafting of the manuscript, acquisition of data. Huseyin Tore: analysis and interpretation of data. Mohammed Alkuwaiti: acquisition of data, analysis and interpretation of data. Christopher Streib: critical revision of manuscript for intellectual content, study supervision.

\section{STUDY FUNDING}

No targeted funding reported.

\section{DISCLOSURE}

The authors report no disclosures relevant to the manuscript. Go to Neurology.org for full disclosures.

\section{REFERENCES}

1. Chung MS, Lee JH, Kim DY, et al. The clinical significance of findings obtained on 3D-FLAIR MR imaging in patients with Ramsay-Hunt syndrome. Laryngoscope 2015;125:950-955.

2. Ramsay HJ. On herpetic inflammations of the geniculate ganglion: a new syndrome and its complications. J Nervous Ment Dis 1907;34:73-96. 


\section{Neurology}

Teaching NeuroImages: Classic Ramsay Hunt syndrome and associated MRI findings

Edward Labin, Huseyin Tore, Mohammed Alkuwaiti, et al.

Neurology 2017;89;e79-e80

DOI 10.1212/WNL.0000000000004239

\section{This information is current as of August 14, 2017}

\section{Updated Information \& Services}

\section{Supplementary Material}

\section{References}

Subspecialty Collections

\section{Permissions \& Licensing}

Reprints including high resolution figures, can be found at: http://n.neurology.org/content/89/7/e79.full

Supplementary material can be found at: http://n.neurology.org/content/suppl/2017/08/14/WNL.0000000000004 239.DC1

This article cites 2 articles, 0 of which you can access for free at: http://n.neurology.org/content/89/7/e79.full\#ref-list-1

This article, along with others on similar topics, appears in the following collection(s):

\section{All Clinical Neurology}

http://n.neurology.org/cgi/collection/all_clinical_neurology

All Imaging

http://n.neurology.org/cgi/collection/all_imaging

\section{MRI}

http://n.neurology.org/cgi/collection/mri

Post-infectious

http://n.neurology.org/cgi/collection/postinfectious_

Information about reproducing this article in parts (figures,tables) or in its entirety can be found online at:

http://www.neurology.org/about/about_the_journal\#permissions

Information about ordering reprints can be found online: http://n.neurology.org/subscribers/advertise

Neurology ${ }^{\circledR}$ is the official journal of the American Academy of Neurology. Published continuously since 1951, it is now a weekly with 48 issues per year. Copyright @ 2017 American Academy of Neurology. All rights reserved. Print ISSN: 0028-3878. Online ISSN: 1526-632X.

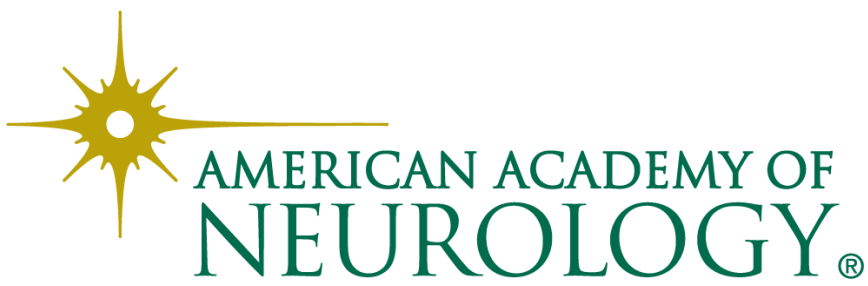

